\title{
Low frequency operation and micro-controller implementation for multilevel quasi Z source inverter in photovoltaic application
}

\author{
Salman Ahmad ${ }^{1}$, Rahim Uddin ${ }^{1}$, and Zahoor Ahmad Ganie ${ }^{1}$ \\ ${ }^{1}$ Islamic University of Science and Technology
}

January 13, 2021

\begin{abstract}
A microcontroller based pulse width modulation implementation for multilevel quasi $\mathrm{Z}$ source inverter is proposed in this paper. The component design of quasi z source inverter (qZSI) is first considered with continuous and discontinuous mode of operations. The low switching frequency operation of multilevel quasi $\mathrm{Z}$ source inverter is proposed in this paper. The detailed modelling for qZSI is then established for effective implementation of PIC microcontroller (PIC 16F877A) for generating the switching signals. A prototype of five level quasi z-source inverter have been developed and the control signal to the gate drivers have been applied by properly adjusting the shoot through and non shoot through switching states. The hardware result shows the effective implementation of the proposed scheme.
\end{abstract}

\section{Hosted file}

Engineering Reports.pdf available at https://authorea.com/users/389226/articles/503835-1owfrequency-operation-and-micro-controller-implementation-for-multilevel-quasi-z-sourceinverter-in-photovoltaic-application 